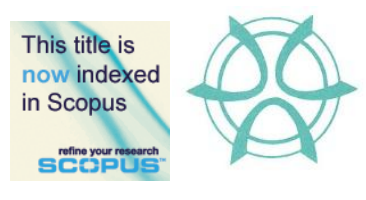

PLANNING MALAYSIA:

Urban Planning and Local Governance

Volume III (2014), Page 81- 94

\title{
UNDERSTANDING OF TOURISTS' PREFERENCES PATTERN: A STUDY IN MELAKA, MALAYSIA
}

\author{
Syakir Amir ${ }^{1}$, Mariana Mohamed Osman ${ }^{2}$, Syahriah Bachok $^{3}$ and \\ Mansor Ibrahim ${ }^{4}$ \\ ${ }^{1,2}, 3 \& 4$ Kulliyyah of Architecture and Environmental Design \\ INTERNATIONAL ISLAMIC UNIVERSITY MALAYSIA
}

\begin{abstract}
Tourism sector is one of the world largest and fastest contributors to the economic sector. The recognition as UNESCO World Heritage City in 2008, has led to the city of Melaka to be the most visited city in Malaysia. There has been a great deal of research devoted to identify the tourist preferences in countries, regions, cities, and other areas. Such estimation is essential for producing comprehensive estimates of tourism economic benefits in an area. This paper presents an evaluation of tourists' preferences among domestic and international tourists visiting Melaka. 1000 tourists were surveyed using diary records survey method. The result shows the purpose of heritage and conservation is the most important factors that motivate their visit to Melaka, while business purpose is the least motivating factors influencing the choice of destinations. It is also found that young, single and professional tourist is the new target market in Melaka.
\end{abstract}

Keyword: tourist preference, Melaka

\footnotetext{
${ }^{1}$ Postgraduate Student (PhD). Email: syakirtrav@ gmail.com

2 Associate Professor at KAED, IIUM, Malaysia. Email: mariana@iium.edu.my

3 Assistant Professor at KAED, IIUM, Malaysia. Email: syahriah@iium.edu.my

${ }^{4}$ Professor at KAED, IIUM, Malaysia. Email: profmansor@iium.edu.my
} 
Syakir Amir, Mariana Mohamed Osman, Syahriah Bachok and Mansor Ibrahim

Understanding of Tourists' Preferences Pattern: A Study in Melaka, Malaysia

\section{INTRODUCTION}

Tourism is the largest and fastest growing industry in the world. While in Malaysia, tourism industry is the second largest industry with the main contributor to the economy after manufacturing sector. There are 25.03 million of tourist arrivals with total receipts of 60.6 billion in 2012. This amount represents an increase of $1.3 \%$ of tourist arrivals and an increase of $3.9 \%$ in total receipts compared with year 2011 (Ministry of Tourism, 2013). Based on the Economic Impact Report 2013 that has been prepared by World Travel and Tourism Council (WTTC), Malaysia generated 1,795,500 employments in 2012 in which $6.5 \%$ of total employment. This includes the employment in direct, indirect and induced sector in relation to tourism industry.

In addition, the total contribution of tourism industry to is RM146.5 billion in 2012. This includes $44.6 \%$ from direct contribution, $15.8 \%$ from induced contribution while $39.6 \%$ from indirect contribution. This figure justifies Malaysia generates large opportunities to the local community involving tourism industry. However, the report by WTTC declares that Malaysia recorded below world average of total contribution of employment in tourism industry (below 1,975,000). In early stage of tourism development in Malaysia three decades ago, Malaysia had the opportunity to host the first Pacific Asian Tourism Association (PATA) Conference in 1972, followed by second PATA Conference in 1986. Later, Malaysia takes a serious step in promoting tourism industry by the launching of the Visit Malaysia Year campaign in 1990, and followed by state visit year, for instance, Visit Terengganu 2013, Visit Melaka Means Visit Malaysia and others. Therefore, the tourism sector has contributed directly to the economy of Malaysia.

However, the issue on local economic benefits in several tourism activities namely accommodation, food and beverages as well as transportation in host destination is widely discussed. This subject is strongly based on purchase behavior of different market segment. Moreover, the inadequate supply in term of tourism facilities to the current demand effects various promotional tactics and decision process. Thus, the aim of this study is to give insight and understanding on existing literature on tourists' preference choice. The study deals with a state in MalaysiaMelaka, where received the influx of tourist every yeark. The paper will therefore comprise two main objectives: (1) to identify the tourists' profile (2) to identify the selection of destination preference choice among tourists. This paper makes an important contribution to the existing literature. This 
paper extends the knowledge of tourist profiling and preferences of Melaka context for which no related researches have been published. The paper is organized in 3 sections. Section 2 reviews the relevant literature and site background. Section 3 describes the data collection procedures. Section 4 reports and discusses the findings.

\section{LITERATURE REVIEW}

\section{Tourist Preferences}

Tourist behavior is determined by various factors. It includes personal and external to the tourist (Swarbrooke and Horner, 1999). The external factors include preferences of the individual tourist, and observed as one of the most vital element and determine the special attributes of the host destination (Murphy, 1985). Many models related to the tourist behavior have been explained and studied by most of the tourism literature (Matheson \& Wall, 1982; Murphy, 1985; Middleton, 1988; Goodall, 1991; Swarbrooke \& Horner, 1999). Based on Murphy (1985), Moutinho (1987) and Goodall (1991) have categorized the four basic travel motivators. (1) Physical motivators such as the quality of food or accommodation, the efficiency of public transport system. (2) Cultural motivators such as the aspiration to experience the foreign customs, history, heritage and culture. (3) Social motivator such as visiting relatives and friends, meeting and business purpose. (4) Fantasy motivators refers to escape from the daily routine, leisure, and holiday. All of the preferences are composed from an image of that particular destination.

Pearce (1988) added that preferences are more specific than motivations, and are revealed by where the tourists go and what the tourists do. Based on Nicolau and Mas (2006), preferences were not specifically analyzed and addressed in certain technique such as conjoint analysis, a method that has been promoted by Suh \& McAvoy (2005), but, research has most frequently used destination attributes and personal characteristics as the dimensions to define the choice of destination. In support, Decrop (2000) claimed that preferences are compared and the one is chosen over the other. The tourists have to decide and choose which of the destination they wish to visit and what are the attributes influenced such decisions. Based on Dellaert, Etterma and Lindh (1998), tourists' decisions are very complex decisions in which the choices and decisions for different elements are interrelated and evolve in a decision process over time, and most of the research on tourists' travel choice highlighted the tourist decision choice as 
Syakir Amir, Mariana Mohamed Osman, Syahriah Bachok and Mansor Ibrahim

Understanding of Tourists'Preferences Pattern: A Study in Melaka, Malaysia

the key element in the travel decision making process. Thus, the decision making process is influenced by a number of internal and external variables. Internal variables refer to psychological elements and external variables refer to non-psychological elements. The criteria that always been highlighted by Um and Crompton (1990) and Sirakaya and Woodside (2005) includes personal (push) factors and destination attributes (pull factors). In 2006, Lam and Hsu mentioned that decision making process leading to the choice of travel destination had not been well researched.

However, list of researches on identifying important attributes affecting destination choice have been conducted, namely Goossens (2000), Heung et al., (2001), Kozak (2002) and Kim \& Prideaux (2005). These studies have contributed to identify many choices and reasons. The likert scale using 5 points and 7 point was used for rating the importance of each choices, and each choices are then arranged in order. The literature of destination attributes have been explored by few researchers, namely prices and distance (Nicolau \& Mas, 2006), climate (Hamilton \& Lau, 2004), quality and pricing (Goossens, 2000). To conclude, the list preferences attributes introduced by Murphy were adopted as well as the method introduced by Decrop, Goossens, Heung et. al., Kozak and Kim was used in this study to compose and identify the preferences among tourists in relation to Melaka.

\section{Study Site: Melaka, Malaysia}

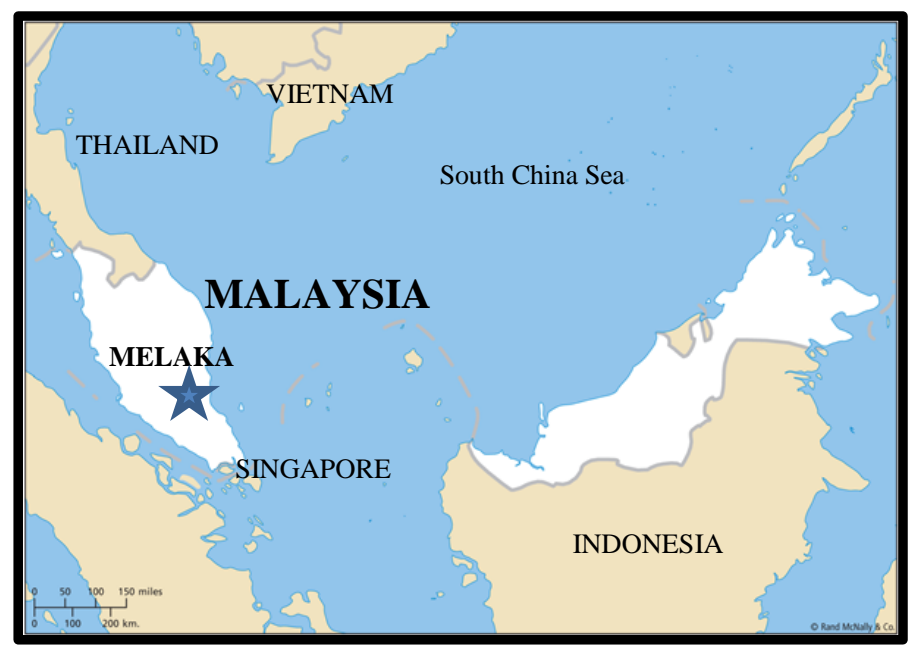

Figure 1: Map of Melaka, Malaysia and surrounding areas 
Melaka is one of the fourteen states of Malaysia. It is located in south western coast of Peninsular Malaysia. The area of Melaka is 1,658 square kilometers and divided into three districts, namely Melaka Tengah, Alor Gajah and Jasin. It takes about two hours travel by road from Kuala Lumpur to Melaka and approximately three hours travel by road to Singapore. Melaka is a well-known historical state that rich with various tourism destinations since decades ago. In fact, tourism under the services sector recorded as the most important economic sector in the state, contributing $46.6 \%$ of GDP.

In attracting the tourist arrival and investors, state government has brought forward a slogan for promotional purpose. The slogan "Visit Melaka Means Visit Malaysia" has launched in early year of 2000. On July 7, 2008, Melaka have been recognized by United Nations Educational, Scientific and Cultural Organization (UNESCO) as a World Heritage City. The city has seen as a historical and heritage witness of 500 years of trading and cultural exchanges between East and West in the Straits of Melaka. UNESCO is now assisting Melaka to preserve and restore the valuable colonial buildings, squares, and churches that have been left by Portuguese, Dutch and British back in 15th- century. After the recognition by UNESCO, Melaka is now becoming the domestic and international tourists' node with recorded the highest number, 13.711 million of tourists in 2012. They successfully attracted 1.366 million of domestic tourists in 2012 as compared to 3.512 million in 2007. In fact, the domestic arrivals grow faster after the UNESCO recognition from 4.857 million in 2007 to 10,199 million in 2012. According to report by the State Tourism Unit (2012), the top five countries of tourist arrivals are China with 652,002 tourists followed by Singapore $(584,088)$, Indonesia $(517,941)$, Taiwan $(356,409)$ and Japan $(123,930)$.

The state government is very committed collaborating with the state tourism players. As a result, rapid development of the tourism industry in Melaka enhance foreign exchange earner, contributing to economic growth, attract investment and create employment opportunities. Melaka State Government more focused in the way of the country's position as a leading foreign tourist destination, as well as enhances ongoing efforts to promote local tourism. Opportunities abound for entrepreneurs, business owners and investors who support the government. 
Syakir Amir, Mariana Mohamed Osman, Syahriah Bachok and Mansor Ibrahim

Understanding of Tourists' Preferences Pattern: A Study in Melaka, Malaysia

\section{DATA COLLECTION AND ANALYSIS}

\section{Diary Records Survey}

In examining the expenditure of tourists, two popular methods have been used in most of the tourism research. They are exit interviews and daily expenditure records during the visit. Exit interviews had been implemented in early $60 \mathrm{~s}$, in which tourists will recall their spending in particular tourism destination or events and record the expenditure. However, Pearce (1988), Howard et. al (1991), Frechtling (1994), and Faulkner \& Raybould (1995) found that many visitors had difficulties to recall their activities with the expenditure. This is due to the error or recall bias in recording the expenditure. Based on Rylander et al. (1995), the errors occur when the complexity of transactions and the length of time between the visit and interview increase. Frechtling (1994) also added it is caused by memory decay. Thus, in order to reduce and eliminate the error, previous researchers have uses diary records survey in which daily activities and expenditure will be recorded during their stay. Previous researches (Howard et al., 1991; Rylander et al., 1995) have used this method to identify the expenditure of an event, but they provide the survey in first day and mailed back to the research team when the visit is completed.

A total of 1500 diary record survey consists of 750 for domestic tourists and 750 international tourists were evenly distributed in selected hotels based on stars ranking in Melaka. Later, the survey successfully collected total amount of 1000 respondents among domestic and international. The survey was administered from March 2014 to April 2014. It includes 6 weekdays, 6 weekends. It was not difficult to monitor and collect the respondents answer sheets because the period was at the peak of the Malaysia tourism season due to school break and Visit Malaysia 2014. The diary record survey was distributed to the tourist during their hotel check-in. After completion, they will return the survey to the receptionist during check-out. Frequency analysis using Statistical Package for Social Science (SPSS) was employed to estimate the means among ten preference choices. The ten preference choices were obtained from tourism subsectors that have been focused and promoted by Melaka state government in their tourism agenda. Before the final estimations were made, a data screening was performed by the application of Kurtosis and Skewness measures in order to test for data normality as the assumption of normality is a prerequisite for analysis. It is found that all of the variables had met the 
assumption of normality as the Kurtosis and Skewness values fell between +1.0 and -1.0 which were considered bivariate normal.

\section{Profile of Respondents}

Table 1: Profile of respondents

\begin{tabular}{|c|c|c|c|c|}
\hline \multirow{2}{*}{\multicolumn{2}{|c|}{ Variables }} & \multirow[t]{2}{*}{ Components } & \multicolumn{2}{|c|}{ Frequencies } \\
\hline & & & Domestic & International \\
\hline \multirow{26}{*}{ 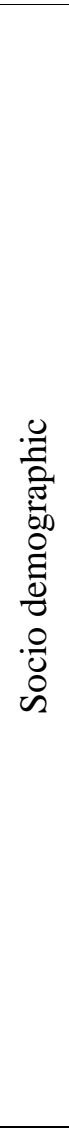 } & Origins & & 525 & 475 \\
\hline & \multirow[t]{2}{*}{ Gender } & Male & 390 & 293 \\
\hline & & Female & 135 & 182 \\
\hline & \multirow[t]{6}{*}{ Age } & $11-20$ & 34 & 5 \\
\hline & & $21-30$ & 266 & 174 \\
\hline & & $31-40$ & 183 & 172 \\
\hline & & $41-50$ & 29 & 64 \\
\hline & & $51-60$ & 10 & 54 \\
\hline & & $61-70$ & 3 & 6 \\
\hline & \multirow[t]{4}{*}{ Marital status } & Single & 288 & 226 \\
\hline & & Married & 233 & 230 \\
\hline & & Widowed & 1 & 5 \\
\hline & & Divorced/ separated & 3 & 14 \\
\hline & \multirow[t]{6}{*}{ Occupation } & Student & 95 & 28 \\
\hline & & Government servant & 140 & 84 \\
\hline & & Private & 194 & 280 \\
\hline & & Pensioner & 6 & 33 \\
\hline & & Self-employed & 90 & 46 \\
\hline & & Unemployed & 0 & 4 \\
\hline & \multirow[t]{7}{*}{ Education level } & SPM/ O-level & 54 & 8 \\
\hline & & $\begin{array}{l}\text { STPM/Matriculation/ } \\
\text { A-Level }\end{array}$ & 3 & 4 \\
\hline & & Certificate & 41 & 21 \\
\hline & & Diploma & 127 & 39 \\
\hline & & Bachelor degree & 240 & 314 \\
\hline & & Master degree & 56 & 71 \\
\hline & & Phd & 4 & 17 \\
\hline \multirow{6}{*}{$\bar{\Xi}$} & \multirow{6}{*}{ Purpose visit } & Holiday & 455 & 374 \\
\hline & & Visit family & 15 & 12 \\
\hline & & Business & 35 & 29 \\
\hline & & Shopping & 6 & 13 \\
\hline & & Education trip & 12 & 13 \\
\hline & & Conference, seminar & 1 & 15 \\
\hline
\end{tabular}


Syakir Amir, Mariana Mohamed Osman, Syahriah Bachok and Mansor Ibrahim

Understanding of Tourists' Preferences Pattern: A Study in Melaka, Malaysia

\begin{tabular}{|c|c|c|c|}
\hline & Health treatment & 1 & 12 \\
\hline \multirow{2}{*}{ First visit? } & Yes & 81 & 369 \\
\hline & No & 444 & 106 \\
\hline \multirow{7}{*}{$\begin{array}{l}\text { Number visiting } \\
\text { (adult) }\end{array}$} & 1 & 273 & 187 \\
\hline & 2 & 216 & 201 \\
\hline & 3 & 19 & 54 \\
\hline & 4 & 9 & 20 \\
\hline & 5 & 7 & 7 \\
\hline & 6 & 1 & 4 \\
\hline & 7 & 0 & 2 \\
\hline \multirow{7}{*}{$\begin{array}{l}\text { Number visiting } \\
\text { (children) }\end{array}$} & 0 & 407 & 444 \\
\hline & 1 & 51 & 6 \\
\hline & 2 & 39 & 18 \\
\hline & 3 & 13 & 6 \\
\hline & 4 & 12 & 1 \\
\hline & 5 & 1 & 0 \\
\hline & 6 & 1 & 0 \\
\hline \multirow{2}{*}{$\begin{array}{l}\text { Returning Melaka } \\
\text { within } 2 \text { years? }\end{array}$} & Yes & 522 & 417 \\
\hline & No & 3 & 57 \\
\hline
\end{tabular}

Table 1 above shows respondents' socio-demographic and travel characteristics. There are total of 525 respondents are domestic tourists and 475 respondents are foreigners. The majority of the respondents were male $(68.3 \%)$, in their $21-30$ range of age $(44 \%) .28 .8 \%$ of local tourists were single while $23 \%$ of international tourists were married. Both domestic and international was private employee $(47.4 \%)$ with qualification of bachelor degree $(55.4 \%)$. This profile pattern indicated clearly that the young single profession was the highest potential market in Melaka. Thus, the provision of tourism activities as well as basic facilities such as accommodation and entertainment in Melaka needs to be concentrated in such market.

Moreover, the majority of respondents visited Melaka for holiday. The respondents were domestic (45.5\%) and international (37.4\%). $44.4 \%$ of domestic tourists were not first-time visitors, while $36.9 \%$ of international tourists were first-time visitors. The study has identified health treatment for purpose of visiting Melaka among international tourist, as a new finding and new segment of potential market. It needs to be explored and widely promoted by the state government. The traveling profile above highlights the 
PLANNING MALAYSIA

Urban Planning and Local Governance

domestic tourist are travelling individually (27.3\%), while the international tourist are more likely traveling with partner $(20.1 \%)$ ). $52.2 \%$ of domestic and $41.7 \%$ of international tourists suggest will coming back to Melaka as Melaka provides a wide range of tourism activities and products hence delivers a high satisfaction to the visitors.

\section{Tourists' Preferences Choice of Destination}

Table 2: Tourists' preferences choice on Melaka

\section{Statistics}

\begin{tabular}{|c|c|c|c|c|c|c|c|c|c|c|}
\hline & 1 & 2 & 3 & 4 & 5 & 6 & 7 & 8 & 9 & 10 \\
\hline Valid & 1000 & 1000 & 1000 & 1000 & 1000 & 1000 & 1000 & 1000 & 1000 & 1000 \\
\hline $\begin{array}{l}\text { Missing } \\
\text { Mean }\end{array}$ & $\begin{array}{l}0 \\
2.3510\end{array}$ & $\begin{array}{l}0 \\
2.7690\end{array}$ & $\begin{array}{l}0 \\
6.1330\end{array}$ & $\begin{array}{l}0 \\
5.5590\end{array}$ & $\begin{array}{l}0 \\
7.8870\end{array}$ & $\begin{array}{l}0 \\
4.6710\end{array}$ & $\begin{array}{l}0 \\
6.3300\end{array}$ & $\begin{array}{l}0 \\
5.5730\end{array}$ & $\begin{array}{l}0 \\
7.8710\end{array}$ & $\begin{array}{l}0 \\
5.8020\end{array}$ \\
\hline
\end{tabular}

Legend:
1. History \& heritage values
2. Cultural values
6. Affordable
3. Recreational \& sports
7. Facilities
4. Shopping heaven
8.Foods
5. Business opportunity
9. Education values
10. Atmosphere \& environment

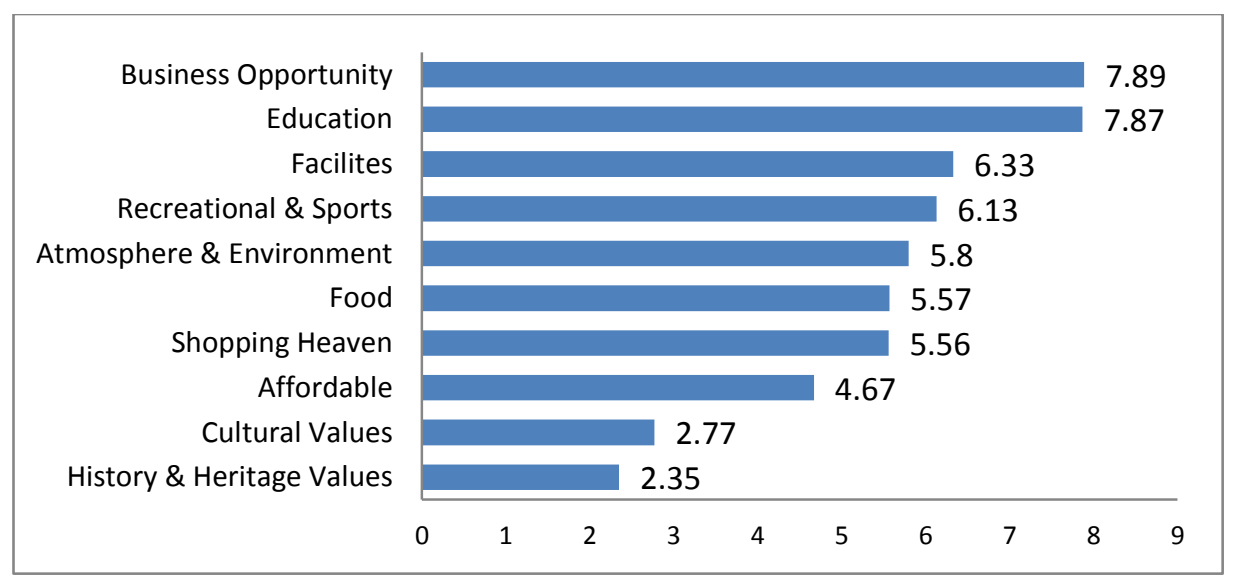

Figure 1: Tourists' preference choice on Melaka 
Syakir Amir, Mariana Mohamed Osman, Syahriah Bachok and Mansor Ibrahim

Understanding of Tourists' Preferences Pattern: A Study in Melaka, Malaysia

In the SPSS descriptive table 2 above, the result indicates the mean of history and heritage value is 2.35 . Since the mean is most nearly to 1 , thus, history and heritage value is the highest preference among tourist to visit Melaka. Next, the mean of cultural values is 2.77 , thus, it is the second highest preference among tourist. Then, it is followed by affordable, 4.67; shopping, 5.56; Food, 5.57; atmosphere and environment, 5.80; Recreational and sports, 6.13; and Facilities, 6.33. Education and business opportunity respectively recorded the lowest preference choices of 7.87 and 7.89.

\section{DISCUSSION}

The purpose of this paper was to analyze the preferences of domestic and international tourists to Melaka, Malaysia. The results showed the history and heritage values as well as cultural values were two main attractions in attracting people to visit Melaka. The tangible heritage product namely A' Famosa, replica of Melaka's Sultanate Palace, Replica of the Flor De Lamar, Porta De Santiago and Stadthuys have been the main identity of Melaka since ages ago. Moreover, intangible cultural values have flourished with multi-racial, rich with tradition and custom in Melaka. That can be seen in the culture of Malay, Chinese, Indian, Baba Nyonya, Chitty, and Portugese. To illustrate detail on the relationship between these two highest preferences chosen and tourist origin, a chi-square test was conducted as below.

Table 3: Chi Square test for tourist origin and history and heritage value preference

\begin{tabular}{|l|r|r|r|}
\hline & Value & df & $\begin{array}{c}\text { Asymp. Sig. (2- } \\
\text { sided) }\end{array}$ \\
\hline Pearson Chi-Square & $83.413^{\mathrm{a}}$ & 9 & .000 \\
Likelihood Ratio & 104.363 & 9 & .000 \\
Linear-by-Linear & 37.413 & 1 & .000 \\
Association & & & \\
N of Valid Cases & 1000 & & \\
\hline
\end{tabular}

a. 6 cells $(30.0 \%)$ have expected count less than 5 . The minimum expected count is .95 . 
PLANNING MALAYSIA

Urban Planning and Local Governance

Symmetric Measures

\begin{tabular}{|ll|r|r|}
\hline & & \multicolumn{1}{|c|}{ Value } & Approx. Sig. \\
\hline \multirow{2}{*}{ Nominal by Nominal } & Phi & .289 & .000 \\
& Cramer's V & .289 & .000 \\
N of Valid Cases & & 1000 & \\
\hline
\end{tabular}

Table 3 above shows a chi-square test of independence. It was conducted to evaluate whether domestic tourists have a greater likelihood to choose history \& heritage values to visit Melaka than international tourist. The two variables were the origin of tourist (domestic and international) and history \& heritage values (rank 1 to 10 ). Based on the result, tourist origin and heritage values preference were found to be significantly related, with (n $=1000), 83.41, \mathrm{p}=.00$, Cramers's $\mathrm{V}=.29$ indicated a medium effect. Thus, the proportions of domestic and international who visit Melaka for the main reason of heritage values were $42.9 \%$ and $44.8 \%$ respectively. Thus, there was a significant association between tourist origin and history \& heritage values preference.

Table 4: Chi Square test for tourist origin and cultural values preference

Chi-Square Tests

\begin{tabular}{|l|r|r|r|}
\hline & Value & df & $\begin{array}{c}\text { Asymp. Sig. (2- } \\
\text { sided) }\end{array}$ \\
\hline Pearson Chi-Square & $81.309^{\mathrm{a}}$ & 9 & .000 \\
Likelihood Ratio & 93.520 & 9 & .000 \\
Linear-by-Linear & 64.003 & 1 & .000 \\
Association & & & \\
N of Valid Cases & 1000 & & \\
\hline
\end{tabular}

a. 5 cells $(25.0 \%)$ have expected count less than 5 . The minimum expected count is 1.90 . 
Syakir Amir, Mariana Mohamed Osman, Syahriah Bachok and Mansor Ibrahim

Understanding of Tourists' Preferences Pattern: A Study in Melaka, Malaysia

Symmetric Measures

\begin{tabular}{|ll|r|r|}
\hline & & \multicolumn{1}{|c|}{ Value } & Approx. Sig. \\
\hline \multirow{2}{*}{ Nominal by Nominal } & Phi & .285 & .000 \\
& Cramer's V & .285 & .000 \\
N of Valid Cases & & 1000 & \\
\hline
\end{tabular}

Table 4 above shows a chi-square test of independence. It was conducted to evaluate whether domestic tourists have a greater likelihood to choose cultural value to visit Melaka than international tourist. The two variables were the origin of tourist (domestic and international) and cultural value (rank 1 to 10). Based on the result, tourist origin and heritage values preference were found to be significantly related, with $(\mathrm{n}=1000), 81.31, \mathrm{p}=$ .00 , Cramers's V $=.285$ indicated a medium effect. Thus, the proportions of domestic and international who visit Melaka for the main reason of cultural value were $44.6 \%$ and $45.3 \%$ respectively. Thus, there was a significant association between tourist origin and cultural value preference.

In other point, the chi-square test results above verified that the state government should not neglect the values of heritage and cultural conservation. This two main attributes have strong relationship with the origin of tourists especially tourists from the modern regions and countries. Heritage landmark building will always symbolize the image of Melaka hence allow tourists to trace the historical origin of the city. The concern of the new aim in driving Melaka as a green technology state, historical buildings will be overlooked than urban development. The concept of maximizing profit and density composition would certainly oppose the historical buildings and heritage preservation. As a result, conservation of heritage and cultural matter is succumbed to modern development and construction projects. Thus, the urban development and heritage conservation in Melaka should be harmony with one another in light of their importance, because both of them fit in the long term and interests of the tourists as well as local community.

The research finding has identified single and budgeted young professional group has the heritage and cultural influenced as the new main market segment of tourist in Melaka. It was proven in the result above, indicated that Melaka is recognized as one of the affordable tourism destination that offer low rate of tourism products. It is proved that the demand of low rate accommodation and other basic tourism services among 
tourists is high. Thus, the state government needs to improve the linkages between the cultural and natural heritage of Melaka with the local community to remain the genuine. The young generation appreciates the heritage and natural projects even though it is small and medium scale, as long as it is genuinely adopting the local culture and community. Unfortunately, the pattern and trend of tourism development in Melaka is mostly towards the provision of new replica heritage attractions and imitation of intangible cultural with modern structures and centers surrounded and eliminate the values of heritage. The intention to diversify the tourism product and imitate of a genuine natural and cultural heritage tourism need to be reviewed systematically.

\section{CONCLUSION}

This study identified and evaluated the choices factors influencing the tourists' choice of Melaka as tourism destination. The result showed that history \& heritage values and cultural value are the two most influential reasons in the choice of Melaka. Melaka turns out to be four most top cities and most favorable destination after Penang, Kuala Lumpur and Selangor. In fact, Melaka is preferred as it is a most affordable place to stay and visit, suitable place to escape and has a lot to offer for domestic as well as international tourists. This study aims to assist the state government to reinforce the strength that Melaka has and improve the weakness, hence do some planning in terms of development and promotional strategies in order to increase the number of tourists. Moreover, it helps Melaka tourism players to better understand on tourist choices pattern hence can develop their effective marketing strategies. In future research, it is recommended that research should focus on identification of tourists' behavior with the integration of tourists' expenditure and satisfaction in Melaka.

\section{REFERENCES}

Decrop, A. (2000). Tourists' decision-making and behavior processes. In A. Pizam, \& Y. Mansfeld (Eds.), Consumer behavior in travel and tourism. NY: The Haworth Hospitality Press.

Dellaert, B.G.C., Etterma, F., \& Lindh, C (1998). Multi-faceted tourist travel decisions: a constraint-based conceptual framework to describe tourists; sequential choice of travel components, Tourism Management, 19 (4), 313-320. 
Syakir Amir, Mariana Mohamed Osman, Syahriah Bachok and Mansor Ibrahim

Understanding of Tourists' Preferences Pattern: A Study in Melaka, Malaysia

Goodall, B. (1991). Understanding holiday choice. In C. Cooper (Ed.), Progress in tourism, recreation and hospitality management. London: Belhaven.

Goossens, C. (2000). Tourism information and pleasure motivation, Annals of Tourism Research, 27, 301-321.

Hamilton, J. M., \& Lau, M. A (2004). The role of climate information in tourist destination choice decision-making. Working Paper FNU-56. Center for Marine and Climate Research. Hamburg, Germany: Hamburg University.

Heung, V. C. S., Qu, H., \& Chu, R. (2001). The relationship between vacation factors and socio-demographic and traveling characteristics: the case of Japanese leisure travelers, Tourism Management, 22(3), 259-269.

Kim, S. S., \& Prideaux, B. (2005). Marketing implications arising from a comparative study of international pleasure tourist motivations and other travel-related characteristics of visitors to Korea, Tourism Management, 26, 347-357

Kozak, M. (2002). Comparative analysis of tourist motivations by nationality and destinations, Tourism Management, 23, 221-232

Lam, T., \& Hsu, H. C. (2006). Predicting behavioral intention of choosing a travel Destination, Tourism Management, 27(4), 589-599.

Mathieson, A., \& Wall, G. (1982). Tourism: economic, physical, and social impacts. London: Harlow.

Middleton, V. (1988). Marketing in travel and tourism. Oxford: Heinemann.

Murphy, P. (1985). Tourism: a community approach. New York: Methuen.

Nicolau, J. L., \& Ma's, F. J. (2006). The influence of distance and prices on choice of tourist destinations: the moderating role of motivations, Tourism Management, 27, 982-996

Pearce, D. (1988). Tourism time budgets, Annuals of Tourism Research, 15(1), $106-121$

Sirakaya, E., \& Woodside, A. G (2005). Building and testing theories of decision making by travelers, Tourism Management, 26, 815-832.

Um, S., \& Crompton, J. L. (1990). Attitude determinants in tourism destination choice. Annuals of Tourism Research, 17(3), 432-448. 